University of Wollongong

Research Online

Faculty of Engineering and Information

Faculty of Engineering and Information

Sciences - Papers: Part B

Sciences

2019

\title{
Microbial electrolysis followed by chemical precipitation for effective nutrients recovery from digested sludge centrate in WWTPs
}

\author{
Sajib Barua \\ University Of Alberta \\ Basem Zakaria \\ University Of Alberta \\ Tae Chung \\ University Of Alberta \\ Faisal I. Hai \\ University of Wollongong, faisal@uow.edu.au \\ Tesfaalem Haile \\ InnoTech Alberta
}

See next page for additional authors

Follow this and additional works at: https://ro.uow.edu.au/eispapers1

Part of the Engineering Commons, and the Science and Technology Studies Commons

Research Online is the open access institutional repository for the University of Wollongong. For further information contact the UOW Library: research-pubs@uow.edu.au 


\title{
Microbial electrolysis followed by chemical precipitation for effective nutrients recovery from digested sludge centrate in WWTPS
}

\author{
Disciplines \\ Engineering | Science and Technology Studies \\ Publication Details \\ Barua, S., Zakaria, B. S., Chung, T., Hai, F. I., Haile, T., Al-Mamun, A. \& Dhar, B. Ranjan. (2019). Microbial \\ electrolysis followed by chemical precipitation for effective nutrients recovery from digested sludge \\ centrate in WWTPs. Chemical Engineering Journal, 361 256-265.
}

\section{Authors}

Sajib Barua, Basem Zakaria, Tae Chung, Faisal I. Hai, Tesfaalem Haile, Abdullah Al-Mamun, and Bipro R. Dhar 
$24{ }^{*}$ Corresponding author: Bipro Ranjan Dhar

25 Phone: +1-780-248-1923

26 E-mail: bipro@ualberta.ca Recovery from Digested Sludge Centrate in WWTPs

\author{
Sajib Barua ${ }^{1}$, Basem S. Zakaria ${ }^{1}$, Tae Chung ${ }^{1}$, Faisal I. Hai², Tesfaalem Haile ${ }^{3}$, Abdullah Al- \\ Mamun ${ }^{4}$, Bipro Ranjan Dhar ${ }^{{ }^{*}}$ \\ ${ }^{1}$ Civil and Environmental Engineering, University of Alberta, 9211-116 Street NW, Edmonton, \\ AB, Canada T6G 1H9 \\ ${ }^{2}$ Strategic Water Infrastructure Laboratory, School of Civil, Mining and Environmental \\ Engineering, University of Wollongong, Wollongong, NSW 2522, Australia \\ ${ }^{3}$ InnoTech Alberta Inc., 1 Oil Patch Drive, Devon, AB, Canada T9G 1A8 \\ ${ }^{4}$ Civil and Architectural Engineering, Sultan Qaboos University, Al-Khoud 123, Muscat, \\ Sultanate of Oman
}




\section{Abstract}

28 A two-step sidestream process was investigated for nitrogen $(\mathrm{N})$ and phosphorous $(\mathrm{P})$ recovery from digested sludge centrate. In the first step, a dual-chamber microbial electrolysis cell (MEC)

30 was used for $\mathrm{N}$ recovery on the cathode. In the second step, $\mathrm{P}$ was recovered as solid precipitates

31 by the addition of $\mathrm{Ca}^{2+}$ or $\mathrm{Mg}^{2+}$ salts in the anodic effluent. The operation of MEC with centrate

32 indicate that $\mathrm{N}$ transport from the anode to the cathode chamber is primarily driven by anodic

33 electron transport rather than diffusional transport. Low concentration of readily biodegradable

34 organics in centrate significantly hindered current density $\left(<0.15 \mathrm{~A} / \mathrm{m}^{2}\right)$ and led to trivial $\mathrm{N}$

35 recovery on the cathode chamber. The addition of primary sludge fermentation liquor (25 vol\%)

36 with centrate as an exogenous source of readily biodegradable organics substantially increased

37 current density up to $6.4 \mathrm{~A} / \mathrm{m}^{2}$, along with high TAN removal efficiency of $53 \pm 5 \%$. The energy requirement was calculated at $5.8 \pm 0.1 \mathrm{kWh} / \mathrm{kg}$-TAN; however, the recovered $\mathrm{H}_{2}$ gas from the

39 cathode was adequate to offset this energy input completely. The addition of $\mathrm{Ca}^{2+}$ salt at a Ca: $\mathrm{P}$

40 molar ratio of 3:1 was optimum for P recovery from the anodic effluent; Mg: P molar ratio of 2:1

41 was found to be optimum for $\mathrm{Mg}^{2+}$ salt addition. However, optimum doses of both salts resulted

42 in maximum $\mathrm{P}$ recovery efficiency of $\sim 85 \%$, while $\mathrm{Mg}^{2+}$ addition provided an additional 38\%

43 TAN removal. These results demonstrate that microbial electrolysis followed by chemical

44 precipitation can promote sustainable nutrients recovery from centrate at municipal wastewater

45 treatment plants where sludge fermentation has already been adopted to provide readily

46 biodegradable carbon source in the biological nutrient removal process.

48 Keywords: Digested sludge centrate; Chemical precipitation; Microbial electrolysis cell;

49 Nitrogen and Phosphorous recovery; Sidestream process; Sludge fermentation liquor 


\section{Introduction}

51 Anaerobic digestion for bio-methane production is one of the most popular approaches for

52 sewage sludge management in centralized wastewater treatment facilities. During the anaerobic

53 digestion process, a substantial amount of inorganic nutrients (primarily nitrogen and

54 phosphorous) is released due to the hydrolysis of particulate organics [1-4]. Anaerobic

55 methanogenic microbiome usually lacks adequate autotrophic metabolism of inorganic nutrients;

56 hence, the liquid effluents from digesters contain a high concentration of these nutrients [1-4]. In

57 many municipal wastewater treatment plants (WWTPs), digested sludge centrate is

58 recycled back to the aerobic biological treatment process (i.e., activated sludge process), which

59 leads to a significant increase in aeration cost due to $15-20 \%$ additional nitrogen $(\mathrm{N})$ load

60 depending on the influent wastewater characteristics [4,5]. Moreover, the extra load imposed by

61 centrate may cause the effluent quality to exceed effluent regulatory limits of nutrient

62 constituents [4].

The energy required for $\mathrm{N}$ removal in conventional two-stage nitrification-denitrification

64 process is estimated to be $12.5 \mathrm{kWh} / \mathrm{kg}-\mathrm{N}$, while emerging anaerobic ammonia oxidation process

$65\left(\right.$ Anammox $\left.{ }^{\circledR}\right)$ requires about $4.2 \mathrm{kWh} / \mathrm{kg}-\mathrm{N}[6,7]$. These biological treatment processes primarily

66 remove $\mathrm{N}$, while it would be more sustainable to recover $\mathrm{N}$ from concentrated wastewater stream

67 like digested sludge centrate. There is a recognized market-value of nutrients available in

68 digested sludge centrate. Currently, the Haber-Bosch process is widely used for

69 ammonia synthesis for various industrial applications [8-10], which require high energy input of

$70 \quad 10-12.5 \mathrm{kWh} / \mathrm{kg}-\mathrm{N}$. Additionally, a significant portion of the phosphorus (P) used for agriculture

71 and other industrial application is obtained by mining, while the global reserve of minable

72 phosphate is expected to be depleted by the end of the twenty-first century [8]. Hence, there has 
73 been a growing interest in developing effective processes for $\mathrm{N}$ and $\mathrm{P}$ recovery from centrate,

74 which can eventually reduce the combined load of nutrients to the mainstream treatment process

75 [4,5]. Different sidestream processes studied for $\mathrm{N}$ and P recovery from digested sludge centrate

76 includes direct stripping, ion exchange, electrodialysis, chemical precipitation and microbial

77 electrochemical technologies [1,3-5,10-15]. Most of these processes focus on recovery of one

78 constituent (either $\mathrm{N}$ or P). Ammonia stripping with acid absorption for ammonium sulfate

79 production has been proven to be an efficient method for $\mathrm{N}$ recovery, while high energy demand

$80(\sim 28 \mathrm{kWh} / \mathrm{kg}-\mathrm{N})$ is one of the major barriers to its widescale adoption [10]. Recovery of

81 ammonia nitrogen using ion exchange resins has often been ruled out due to high regeneration

82 cost as well as deterioration of their ion exchange capacities after multiple regeneration cycles

83 [11]. Electrodialysis (ED), an emerging process which deploys a series of ion exchange

84 membranes with applied electric potential, can efficiently recover $\mathrm{N}$ from various wastewater

85 streams $[4,10]$. A recent study by Ward et al.[10] reported that the electrodialysis system could

86 attain concentrated ammonium- $\mathrm{N}$ solution from digester sludge centrate with a relatively lower

87 energy input of $4.9 \pm 1.5 \mathrm{kWh} / \mathrm{kg}-\mathrm{N}$. However, frequent cleaning of multiple membrane modules

88 remained a concern, as membrane fouling can lead to higher energy inputs.

Chemical precipitation of nutrients as struvite (magnesium ammonium phosphate) from

90 various wastewater stream has been predominantly investigated for P recovery. Recovered

91 struvite can be directly utilized as a slow-release fertilizer $[4,14,16,17]$. Along with the addition

92 of magnesium $\left(\mathrm{Mg}^{2+}\right)$ salt, struvite process may consume a significant amount of base chemicals

93 due to the requirement of high $\mathrm{pH}$ conditions for struvite precipitation [13]. Struvite process can

94 provide up to $90 \% \mathrm{P}$ recovery from wastewater with minimal $\mathrm{N}$ removal: theoretically, per gram

95 of P removal as struvite removes 0.45 gram of $\mathrm{N}$ [4]. In comparison with struvite, only a few 
studies reported efficient $\mathrm{P}$ recovery as calcium phosphate $(\mathrm{CaP})$ from digested sludge centrate

$97[15,18]$. To the best of our knowledge, to date, no studies have compared P recovery efficiencies

98

99

100

101

102

103

104

105

106

107

108

109

110

111

112 has been rarely investigated. A recent study by Yuan and Kim [13] reported that a small

113 concentration of readily biodegradable organics in digested sludge centrate resulted in low current

114 density and inferior cathodic nutrients recovery in a MEC. Thus, inadequate readily biodegradable

115 organics could be a possible reason that made digested sludge centrate a relatively unattractive

116 stream for nutrients recovery with microbial electrochemical systems. Therefore, the development

117 of an efficient engineering strategy to improve current density and nutrients recovery from centrate 
would be essential to promote the microbial electrochemical system as a sidestream process for centrate, and thereby reduce nutrients load to mainstream biological process.

It is apparent that none of the abovementioned technologies can be used as a standalone process for simultaneous $\mathrm{N}$ and $\mathrm{P}$ recovery from digested sludge centrate. More efforts in developing integrated processes are required to promote sustainable nutrients recovery from centrate. Herein, a dual-chamber MEC having CEM followed by chemical precipitation was investigated as an integrated process for $\mathrm{N}$ and $\mathrm{P}$ recovery from digested sludge centrate collected from a full-scale municipal WWTP. First, primary sludge fermentation liquor was assessed as a supplementary source of readily biodegradable organics for enhancing electrochemical performance of MEC and ensuring efficient recovery of ammonium nitrogen on the cathode chamber. Second, the effluent from MEC was further assessed for P recovery through chemical precipitation with the addition of $\mathrm{Ca}^{2+}$ and $\mathrm{Mg}^{2+}$ salts. The overall goal of this current study was to determine if this integrated process of microbial electrolysis followed by chemical precipitation with $\mathrm{Ca}^{2+}$ or $\mathrm{Mg}^{2+}$ could lead to a technically viable option for nutrients recovery from digested sludge centrate in municipal WWTPs.

\section{Materials and methods}

\subsection{MEC operation for nitrogen removal and recovery}

A bench-scale dual-chamber MEC constructed from plexiglass was used in this study. The design of MEC is similar to the one previously described by Zakaria et al. [32]. Briefly describing the design, the working volumes of anode and cathode chambers were $400 \mathrm{~mL}$ and $140 \mathrm{~mL}$, respectively (see Fig. 1a). A photograph of the MEC is provided in the Supplementary Information. Bundles of carbon fibers (2293-A, 24A Carbon Fiber, Fibre Glast Development Corp., Ohio, USA) integrated with a stainless-steel frame was used as the anode electrode. 
141 Carbon fibers were pretreated according to a method previously described by Dhar et al. [33]. A 142 stainless-steel mesh (Type 304, McMaster Carr, OH, USA) was used as the cathode electrode.

143 In this study, the anode and cathode chambers were separated by a CEM (CMI-7000,

144 Membranes International Inc, USA). Ag/AgCl reference electrode (MF-2052, Bioanalytical

145 System Inc., WestLafayette, IN, USA) was placed within $\sim 1 \mathrm{~cm}$ of the anode electrode. The

146 anode potential was set at $-0.4 \mathrm{~V}$ vs. Ag/AgCl using a multi-channel potentiostat system

147 (Squidstat Prime, Admiral Instruments, Phoenix, AZ, USA) throughout the experiment. Effluent

148 from a mother MEC was used as the inoculum for the enrichment of anode biofilms as

149 previously reported by Zakaria et al. [32] and $25 \mathrm{mM}$ of sodium acetate medium supplemented

150 mineral nutrients, and $50 \mathrm{mM}$ phosphate buffer served as the substrate for the enrichment of

151 anode biofilms. The detailed composition of the mineral nutrients can be found in the literature

152 [33]. The MEC was operated at room temperature $\left(22 \pm 1^{\circ} \mathrm{C}\right)$, and both the anolyte and catholyte

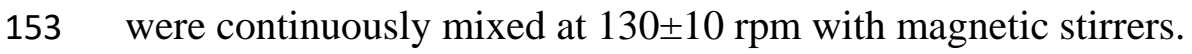

During the enrichment process of anodic biofilms, MEC was operated in semi-continuous mode (i.e., $180 \mathrm{~mL}$ of fresh substrate medium was fed to the anode chamber using a syringe on a 156 daily basis) until a repeatable peak current of $10.4 \pm 0.9 \mathrm{~A} / \mathrm{m}^{2}$ was observed. Then, nitrogen 157 recovery experiments were conducted with digested sludge centrate, centrate supplemented with 158 exogenous readily biodegradable organics (acetate and ethanol), and centrate mixed with primary 159 sludge fermentation liquor (see Fig. 1b). During Cycle-1 and 2, MEC was operated with real 160 digested centrate. Anaerobic digester sludge was collected from a full-scale mesophilic 161 anaerobic digester at the Gold Bar Wastewater Treatment Plant, Edmonton, Alberta, Canada.

162 Anaerobic digester sludge was centrifuged at 18,670xg for $30 \mathrm{~min}$, and the centrate was collected 163 for experiments. During Cycle-3, 4, and 5, MEC was operated with centrate supplemented with 
164 three different concentrations of exogenous readily biodegradable organics (435, 860, and 1355

165

mg COD/L, respectively). A mixture of acetate and ethanol (COD ratio of 1:1) was used as exogenous readily biodegradable organics. During Cycle-6 and 7, MEC was operated with a mixture of digested sludge centrate (75 vol\%) and liquor from primary sludge fermentation (25 vol\%). For sludge fermentation experiment, primary sludge was collected from Gold Bar Wastewater Treatment Plant, Edmonton, Alberta, Canada. The fermentation experiment was performed in a bench-scale glass anaerobic bioreactor (working volume of 2 L) equipped with a stirring shaft. The sludge was sparged with ultra-pure nitrogen gas (99.999\%) for three minutes. The fermentation process was operated for 7 days at room temperature $\left(22 \pm 1^{\circ} \mathrm{C}\right)$, and the reactor media was stirred with a mixer at $300 \mathrm{rpm}$. After 7 days of operation, fermented sludge was centrifuged at 18,670xg for $30 \mathrm{~min}$, and the supernatant (i.e., fermentation liquor) was collected and used for experiments (Cycle-6 and 7). Table 1 shows the average characteristics of centrate, primary sludge, and fermentation liquor. All experiments were conducted in fed-batch mode. Before each cycle, the cathode chamber was evacuated completely and cleaned multiple times with tap water to remove any residual ammonium that can influence the results of the following cycle.

\subsection{Chemical precipitation experiments for $\mathbf{P}$ recovery}

We performed nutrients precipitation experiments with anodic effluent collected during Cycle-5. The average soluble reactive phosphorous (SRP) and total ammonia-nitrogen (TAN) concentrations in the effluent were $1387 \pm 51 \mathrm{mg} / \mathrm{L}$ and $451 \pm 15 \mathrm{mg} / \mathrm{L}$, respectively. For precipitation experiments, specific amounts of $\mathrm{CaCl}_{2} \cdot 2 \mathrm{H}_{2} \mathrm{O}$ or $\mathrm{MgCl}_{2} \cdot 6 \mathrm{H}_{2} \mathrm{O}$ salts are added into centrifuge vials having $50 \mathrm{~mL}$ of anodic effluent samples. The corresponding molar ratios of Ca to $\mathrm{P}$ and $\mathrm{Mg}$ to $\mathrm{P}$ are summarized in Table 2. These ratios were selected based on the possible 
precipitation of $\mathrm{Ca}_{3}\left(\mathrm{PO}_{4}\right)_{2}$ or $\mathrm{Ca}_{5}(\mathrm{OH})\left(\mathrm{PO}_{4}\right)_{3}$ and struvite $\left(\mathrm{MgNH}_{4} \mathrm{PO}_{4} \cdot 6 \mathrm{H}_{2} \mathrm{O}\right)$, respectively, as previously suggested in the literature [34,35]. Phosphorous precipitation tests with $\mathrm{Ca}^{2+}$ salt was performed without any $\mathrm{pH}$ adjustment; $\mathrm{pH}$ of the anode effluent was 6.8. In contrast, precipitation tests with $\mathrm{Mg}^{2+}$ salt were carried out at two different $\mathrm{pH}$ (6.8 and 8.6); $\mathrm{pH}$ was adjusted to 8.6 using $3 \mathrm{M} \mathrm{NaOH}$. After addition of $\mathrm{Ca}^{2+}$ or $\mathrm{Mg}^{2+}$ salts, vials were tightly capped, and liquids were mixed with a vortex mixer for 2 minutes. After 4 hours of settling period, vials were centrifuged at 18,670xg for $30 \mathrm{~min}$, and solid precipitates were collected. The solid precipitates were examined for elemental composition, and supernatant samples were analyzed for COD, TAN, and SRP concentrations. All experiments were conducted at room temperature $\left(22 \pm 1^{\circ} \mathrm{C}\right)$.

\subsection{Analytical methods}

Applied voltage and current were recorded every five minutes in a computer using Squidstat User Interface software (Squidstat Prime, Admiral Instruments, USA). COD, TAN, and SRP concentrations were measured using HACH reagent kits (HACH, Loveland, Colorado, USA). For analysis of soluble parameters, samples were filtered with $0.45 \mu$ m nylon syringe filter. $\mathrm{pH}$ was measured using a bench-top pH meter (Accumet AR15, Fisher Scientific, Pittsburgh, PA, USA), and solution conductivities were measured using a portable conductivity meter (Extech EC100, EXTECH Instruments, USA). The concentrations of VFAs (acetate, propionate, and butyrate) were measured using an ion chromatograph (Dionex ICS-2100, Dionex, Sunnyvale, CA) equipped with an electrochemical detector (ECD) and microbore AS19 column. The elemental composition of the solid precipitates was examined with scanning electron microscopy (SEM) with energy dispersive X-ray spectroscopy (EDX). For analysis of the elemental composition, solid precipitates were air dried and mounted on SEM stubs. Then, the samples 
210 were sputter coated with gold and examined using SEM (Zeiss Sigma 300 VP-FESEM, Carl

211 Zeiss, Cambridge, UK).

\section{$212 \quad 2.4$ Calculations and economic assessment}

213 Current density was calculated based on the projected area of membrane $\left(0.0038 \mathrm{~m}^{2}\right)$, as

214 previously described in the literature $[9,33,36]$. The anodic TAN removal efficiency was

215 calculated from the difference in initial and final TAN concentration of the anodic liquid during

216 a fed-batch cycle. The cathodic TAN recovery efficiency was calculated from the amount of

217 TAN accumulated in the cathode chamber and the amount of TAN removed from the anode

218 chamber during a fed-batch cycle. A preliminary economic assessment for MEC was performed

219 based on per kg TAN removal from centrate. Average experimental results from Cycle-6 and 7

220 was used for these calculations. Electrical energy input (kWh) to MEC for an entire fed-batch

221 cycle was computed from the current and applied voltage data recorded with time, as previously

222 described in the literature [37]. The cost of electrical energy input and monetary value of $\mathrm{H}_{2}$

223 produced from MEC were estimated at $\$ 0.07 / \mathrm{kWh}$ and $\$ 8 / \mathrm{kg}-\mathrm{H}_{2}$, respectively $[38,39]$.

\section{3. Results and discussion}

\section{$225 \quad 3.1 \mathrm{~N}$ recovery from centrate}

\section{$226 \quad 3.1 .1 \mathrm{~N}$ recovery and current density from centrate}

227 Fig. 2a shows current density with time during MEC operated with digested sludge

228 centrate (Cycle-1 and 2). The peak current densities from MEC in both cycles (Cycle-1: 0.11

$229 \mathrm{~A} / \mathrm{m}^{2}$; Cycle 2: $0.13 \mathrm{~A} / \mathrm{m}^{2}$ ) were substantially lower than the peak current density of $10.4 \pm 0.9$

$230 \mathrm{~A} / \mathrm{m}^{2}$ observed with $25 \mathrm{mM}$ sodium acetate medium during enrichment of anode biofilms,

231 indicating that current density was limited due to the lack of readily biodegradable organics 
232 in centrate. As expected, a major portion of SCOD in centrate was unutilized by anodic

233 microbial communities (Fig. 2b); SCOD removal efficiencies were ranged from 14\% (Cycle-1)

234 to 26\% (Cycle-2). After the operation of both cycles, TAN concentrations in the anode chamber

235 remained almost unchanged (Fig. 2c), while TAN concentration slightly increased in the cathode

236 chamber (Fig. 2d). Thus, it is possible that additional ammonia nitrogen has been released

237 through hydrolysis of particulate organics in the anode chamber. In MECs, ammonium transport

238 through CEM comprises of migration (driven by electric field) and diffusion (driven by

239 concentration gradient) mechanisms [23,24]. A few studies previously suggested that alkaline

$240 \mathrm{pH}(\sim 8.8)$ and high TAN levels in source-separated urine (>3 g/L) might trigger diffusional

241 ammonium transport from the anode to the cathode chamber [23,24]. In contrast, the results of

242 this current study demonstrated that migration would be the primary mechanism for ammonium

243 transport from centrate possibly due to relatively lower $\mathrm{pH}(\sim 7.9)$ and TAN level ( 1 g/L).

244 Therefore, increasing current density in MEC would be crucial to enhance ammonium migration 245 to the cathode chamber.

\subsubsection{Enhanced N recovery from centrate supplemented with exogenous electron donors}

247 In response to the addition of exogenous readily biodegradable organics at different

248 concentrations, current densities in MEC noticeably increased as compared to centrate alone

249 (Fig. 3a). The peak current densities in Cycle-3, 4, and 5 were 2.4, 8.4, and $9.4 \mathrm{~A} / \mathrm{m}^{2}$,

250 respectively. Anodic TAN concentrations were observed to decrease as current densities

251 increased (Fig. 3b). The addition of readily biodegradable organics at high concentrations

252 (Cycle-4: 860 mg SCOD/L; Cycle-5: 1355 mg SCOD/L) showed a considerable decrease in

253 anodic TAN concentrations. During Cycle 4 and Cycle-5, TAN concentrations in the anode

254 chamber decreased from 1165 and 1178 mg/L to 594 and 456 mg/L, respectively; and TAN 
255 concentrations in the cathode chamber increased up to $1152 \mathrm{mg} / \mathrm{L}$ (Cycle-4) and $1537 \mathrm{mg} / \mathrm{L}$

256 (Cycle-5), respectively (Fig. 3c). Thus, anodic TAN removal efficiencies were 49\% (Cycle-4)

257 and 61\% (Cycle-5). Correspondingly, TAN fluxes through the membrane during these cycles

258 were 13 g-TAN/m²-d (Cycle-4) and 18 g-TAN/m²-d (Cycle-5). However, transported ammonium

259 recovery efficiencies on the cathode were $70 \%$ (Cycle-4) and 73\% (Cycle-5). A portion of the

260 transported ammonium (27-30\%) were possibly lost through stripping as ammonia gas due to the

261 highly alkaline cathodic $\mathrm{pH}(\sim 12)$ as a result of proton reduction to $\mathrm{H}_{2}$ gas on the cathode

$262\left(2 \mathrm{H}^{+}+2 \mathrm{e}^{-} \rightarrow \mathrm{H}_{2}\right)$. The detailed $\mathrm{pH}$ profiles are provided in the Supplementary Information. In

263 comparison, low concentration of exogenous readily biodegradable organics (Cycle-3: $435 \mathrm{mg}$

264 SCOD/L) exhibited relatively lower N recovery efficiency. As shown in Fig. 3d, a substantial

265 decrease in SCOD concentrations were observed in comparison with MEC operation with

266 digested sludge centrate alone, indicating the lower biodegradability of residual organics in

267 digested centrate. As expected, there was no change in SRP concentrations due to the use of

268 CEM (Fig. 3e). Overall, these results support that the addition of exogenous readily

269 biodegradable organics favored current density and nitrogen recovery from digested centrate.

$270 \quad$ 3.1.3 Efficient $\mathbf{N}$ recovery from centrate supplemented with sludge fermentation liquor

271 Because the addition of exogenous readily biodegradable organics improved current density and

272 N recovery, primary sludge fermentation liquor was assessed as a potential source of readily

273 biodegradable organics (Cycle-6 and 7) (Fig. 4). The TAN and SRP concentrations in digested

274 sludge centrate were not substantially diluted by the addition of fermentation liquor (25\% by

275 volume). The operation of MEC with a mixture of centrate and fermentation liquor exhibited

276 peak current density of $6.4 \mathrm{~A} / \mathrm{m}^{2}$ (Cycle-6) and 6.2 A/m² (Cycle-7) (Fig. 4a). Fig. 4b and 4c

277 show the changes in TAN concentrations in anode and cathode chambers over the course of 
278 these two cycles. On average, TAN concentrations in the anode chamber decreased from $957 \pm 35$

$279 \mathrm{mg} / \mathrm{L}$ to $455 \pm 45 \mathrm{mg} / \mathrm{L}$, and TAN concentrations in the cathode chamber increased to $1194 \pm 117$

$280 \mathrm{mg} / \mathrm{L}$. Average anodic TAN removal efficiency and corresponding flux through the membrane

281 were $53 \pm 5 \%$ and $26 \pm 4 \mathrm{~g}-\mathrm{TAN} / \mathrm{m}^{2}$-d. On average, $85 \pm 14 \%$ of the transported TAN was

282 recovered on the cathode. This performance was comparable with the operation of MEC with

283 centrate supplemented with a high concentration of ethanol and acetate (i.e., Cycle-5). Average

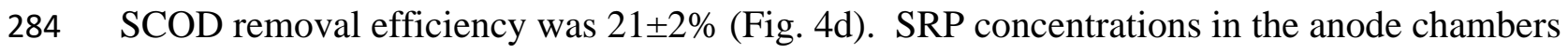

285 were almost unchanged in both cycles, which is also consistent with previous cycles (Fig. 4e).

286 To the best of our knowledge, the results of this study first evidently demonstrated that the

287 addition of fermentation liquor could provide an adequate quantity of readily biodegradable

288 organics in centrate to promote nitrogen recovery with microbial electrochemical

289 systems. Several studies previously demonstrated that primary sludge fermentation liquor could

290 serve as a promising exogenous carbon source for biological nutrients removal (BNR) process in

291 WWTPs [40,41]. In fact, many WWTPs across North America already adopted sludge

292 fermentation to produce short-chain volatile fatty acids for providing exogenous electron donors

293 to the BNR process. We envision that a portion of sludge fermentation liquor can be diverted to

294 MEC for enhancing $\mathrm{N}$ recovery from centrate.

295 Based on the results obtained from Cycle-6 and 7, the average electrical energy

296 consumption per kg of TAN transport from the anode chamber to the cathode

297 chamber was estimated at $5.8 \pm 0.1 \mathrm{kWh}$. Thus, electricity cost was calculated at $\$ 0.40 \pm 0.01 / \mathrm{kg}$ -

298 TAN. Simultaneously with N recovery, $\mathrm{H}_{2}$ gas can be recovered on the cathode. An average

$299 \mathrm{H}_{2}$ production per cycle was $189 \pm 33 \mathrm{~mL}$, which corresponds to $\mathrm{H}_{2}$ productivity of $0.08 \pm 0 \mathrm{~kg}-$

$300 \mathrm{H}_{2}$ per kg of TAN removal. The monetary value of $\mathrm{H}_{2}$ that can be simultaneously 
301 produced during MEC operation was estimated at $\$ 0.64 \pm 0.1 / \mathrm{kg}-\mathrm{TAN}$, resulting in a net financial gain of $\$ 0.23 \pm 0.01 / \mathrm{kg}-\mathrm{TAN}$, which does not include the economic value of concentrated ammonium solution. This preliminary economic evaluation based on the bench-scale experimental results indicates the potential of energy positive or energy neutral operation of MEC for $\mathrm{N}$ recovery from digested sludge centrate. It must be noted that further comprehensive economic assessment should be done at pilot-scale. Furthermore, to become a competitive technology for $\mathrm{N}$ recovery, anodic TAN removal efficiency (53 $\pm 5 \%)$ and rate $(26 \pm 4 \mathrm{~g}$ TAN/m²reported for MECs operated with real or synthetic urine. Haddadi et al. [23] reported N removal rate of $8.5 \mathrm{~g}-\mathrm{N} / \mathrm{m}^{2}$-d in a MEC operated with synthetic urine. In contrast, Kuntke et al. [31] reported high ammonium removal rate of $173.4 \mathrm{~g}-\mathrm{N} / \mathrm{m}^{2}-\mathrm{d}$ in a MEC operated with urine;

312 however, ammonium removal efficiency was only 30\%. As nitrogen recovery from digested 313 centrate is primarily driven by migration or charge neutrality, improving current density would 314 be critical to enhance $\mathrm{N}$ recovery. Notably, the current density can be significantly enhanced 315 with multiple anode modules [42,43]. Additionally, more concentrated ammonium solution can 316 be achieved by increasing the ratio between dilute to concentrate volumes $\left(\mathrm{V}_{\mathrm{D} / \mathrm{C}}\right)$ until a certain 317 limit [28]. In this study, a concentration factor of $\sim 1.25$ with $53 \pm 5 \%$ TAN removal was attained 318 at $\mathrm{V}_{\mathrm{D} / \mathrm{C}}$ of 2.86. This result is comparable with a concentration factor of $\sim 1.75$ (63\% ammonium 319 removal from synthetic urine) at $\mathrm{V}_{\mathrm{D} / \mathrm{C}}$ of 2 reported by a previous study [28].

\subsection{P recovery from MEC effluent}

321 Fig. 5 shows the changes in SRP and TAN concentrations in the anodic effluent after chemical 322 precipitation experiments at different conditions. The addition of $\mathrm{Ca}^{2+}$ salt induced a significant 323 reduction in SRP concentrations, while TAN concentration remained unchanged. At Ca:P molar 
324 ratio of $1.5: 1\left(\mathrm{Ca}^{2+}{ }_{\mathrm{pH}=6.8}(1)\right)$, SRP concentration decreased by $75 \pm 1 \%$. In contrast, comparable

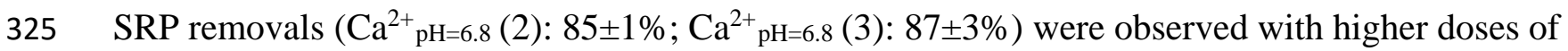

$326 \mathrm{Ca}^{2+}$ salt. The SEM-EDX analysis suggested that the solid precipitate collected from $\mathrm{Ca}^{2+}{ }_{\mathrm{pH}=6.8}$

327 (2) test was primarily composed of two major elements, namely, $\mathrm{P}$ and Ca (Fig. 6a). Thus,

328 P was efficiently recovered without any $\mathrm{pH}$ adjustment of MEC effluent. In contrast, SRP and

329 TAN concentrations did not change after addition of various doses of $\mathrm{Mg}^{2+}$ salt at pH 6.8 (i.e., no

$330 \mathrm{pH}$ adjustment). While $\mathrm{pH}$ of the MEC effluent increased to 8.6, both SRP and TAN

331 concentrations remarkably decreased with the addition of $\mathrm{Mg}^{2+}$ salt, which is consistent with

332 previous studies reported that alkaline $\mathrm{pH}$ would be essential for struvite precipitation $[4,12,16]$.

333 In $\mathrm{Mg}^{2+}{ }_{\mathrm{pH}=8.6}(1)$ test, the average removals of SRP and TAN were $77 \pm 1 \%$ and $38 \pm 3 \%$,

334 respectively. The addition of higher doses of $\mathrm{Mg}^{2+}$ salt did not result in further improvement in

335 TAN removal efficiencies, while SRP removal efficiencies slightly improved $\left(\mathrm{Mg}^{2+}{ }_{\mathrm{pH}=8.6}(2)\right.$ :

$33684 \pm 2 \% ; \mathrm{Mg}^{2+}{ }_{\mathrm{pH}=8.6}$ (3): $84 \pm 1 \%$ ). As shown in Fig. 6b, the EDX spectrum confirmed the major

337 components of the solid precipitates to be $\mathrm{Mg}(17.7 \%)$ and $\mathrm{P}(13.7 \%)$, which is comparable to

338 that of the elemental composition of standard struvite (Mg: 9.79\%; P: 13.49\%) previously

339 reported in the literature [44]. The absence of $\mathrm{N}$ peak was also consistent with the previous

340 literature, which could be due to its light weight [44]. In this study, optimum doses of $\mathrm{Ca}^{2+}(\mathrm{C}: \mathrm{P}$

341 of 3:1 at $\mathrm{pH}=6.8 ; 4.8 \mathrm{~g} \mathrm{Ca}^{2+}$ salt/g SRP) or $\mathrm{Mg}^{2+}\left(\mathrm{Mg}: \mathrm{P}\right.$ of 2:1 at $\mathrm{pH}=8.6 ; 4.5 \mathrm{~g} \mathrm{Mg}^{2+}$ salt/g SRP)

342 salts exhibited comparable maximum P recovery efficiencies from MEC effluent. A comparison

343 of the results indicated that $\mathrm{Mg}^{2+}$ addition at $\mathrm{pH} 8.6$ could provide some additional benefit due to 344 further removal of TAN, while the $\mathrm{pH}$ adjustment would induce some additional chemical costs $345 \quad[45,46]$. 
To satisfy effluent discharge standard, the effluent (supernatant) from chemical

347 precipitation process can be recycled to a mainstream treatment process for removal of

348 unrecovered nutrients. The low $\mathrm{pH}$ of this stream can influence the performance of mainstream

349 biological treatment process. It is evident that $\mathrm{Mg}^{2+}$-based process can provide an advantage

350 over $\mathrm{Ca}^{2+}$ addition due to relatively higher $\mathrm{pH}(\geq 7)$ in the final effluent (See Supplementary

351 Information). For $\mathrm{Ca}^{2+}$-based process, post-adjustment of $\mathrm{pH}$ may be required before recycling

352 supernatant liquid stream. This would be particularly important for activated sludge systems

353 already having alkalinity limitations due to complete nitrification. However, a comprehensive

354 techno-economic assessment would be required for the selection of an optimum process.

355 Additionally, the recovered precipitates from both processes should be assessed for potential

356 environmental risks, including pathogens, antibiotic resistance genes, heavy metals, and

357 micropollutants, as suggested by recent studies $[14,47,48]$. To the best of our knowledge, this

358 study first provides a systematic comparison between the phosphorous recovery efficiencies with

$359 \mathrm{Ca}^{2+}$ and $\mathrm{Mg}^{2+}$ salts. It must be asserted that $\mathrm{P}$ precipitation with $\mathrm{Mg}^{2+}$ salt has been extensively

360 explored, while limited information is available in the literature on the $\mathrm{P}$ recovery with $\mathrm{Ca}^{2+}$ salt

$361[15,18]$. Therefore, our results substantiate the importance of further comprehensive assessment

362 of various options for P precipitation from centrate.

\section{4. Conclusions}

364 The use of primary sludge fermentation liquor as a supplementary source of readily

365 biodegradable organics to digested sludge centrate appears to be a promising solution to boost

366 current density and subsequent $\mathrm{N}$ recovery in a dual-chamber MEC. The addition of

367 fermentation liquor (25\% by volume) with centrate exhibited average anodic TAN removal

368 efficiency and rate of $53 \pm 5 \%$ and $26 \pm 4$ g-TAN $/ \mathrm{m}^{2}$-d, respectively. This performance was almost 
369 comparable with the addition of acetate and ethanol as exogenous electron donors for anodic

370 microbial communities. Additionally, recovered $\mathrm{H}_{2}$ gas from the cathode was adequate to offset

371 the cost of electrical energy input to the process. Under optimum precipitation conditions,

372 maximum P recovery efficiencies from MEC effluents that could be achieved by either $\mathrm{Ca}^{2+}$ or

$373 \mathrm{Mg}^{2+}$ salts were about $85 \%$. Thus, the results of this study demonstrated that MEC followed by

374 chemical precipitation can act as an efficient sidestream process for $\mathrm{N}$ and $\mathrm{P}$ recovery from

375 centrate. The process should be investigated in pilot-scale for further optimization and

376 application at municipal wastewater treatment plants.

\section{Acknowledgements}

378 This research was financially supported by the University of Alberta Faculty of Engineering

379 Start-up Grant and Natural Sciences and Engineering Research Council of Canada Discovery

380 Grant (RG PIN-2017-05608). We would like to thank Mr. Abdul Mohammed at the Gold Bar

381 Wastewater Treatment Plant (Edmonton, Alberta, Canada) for his assistance in sludge sampling. 


\section{References}

[1] M.S. Romero-Güiza, S. Astals, J. Mata-Alvarez, J.M. Chimenos, Feasibility of coupling anaerobic digestion and struvite precipitation in the same reactor: Evaluation of different magnesium sources, Chem. Eng. J. (2015). doi:10.1016/j.cej.2015.02.057.

[2] N. Marti, A. Bouzas, A. Seco, J. Ferrer, Struvite precipitation assessment in anaerobic digestion processes, Chem. Eng. J. (2008). doi:10.1016/j.cej.2007.10.023.

[3] F. Zeng, Q. Zhao, W. Jin, Y. Liu, K. Wang, D.J. Lee, Struvite precipitation from anaerobic sludge supernatant and mixed fresh/stale human urine, Chem. Eng. J. (2018). doi:10.1016/j.cej.2018.03.088.

[4] C. Eskicioglu, G. Galvagno, C. Cimon, Approaches and processes for ammonia removal from side-streams of municipal effluent treatment plants., Bioresour. Technol. 268 (2018) 797-810. doi:10.1016/j.biortech.2018.07.020.

[5] T.A. Constantine, North american experience with centrate treatment technologies for ammonia and nitrogen removal, Water Environ. Fed. 11 (2006) 5271-5281. doi:10.2175/193864706783763291.

[6] S. Lackner, E.M. Gilbert, S.E. Vlaeminck, A. Joss, H. Horn, M.C.M. van Loosdrecht, Full-scale partial nitritation/anammox experiences - An application survey, Water Res. 55 (2014) 292-303. doi:10.1016/j.watres.2014.02.032.

[7] P. Kuntke, T.H.J.A. Sleutels, M. Rodríguez Arredondo, S. Georg, S.G. Barbosa, A. ter Heijne, H.V.M. Hamelers, C.J.N. Buisman, (Bio)electrochemical ammonia recovery: progress and perspectives, Appl. Microbiol. Biotechnol. 102 (2018) 3865-3878. doi:10.1007/s00253-018-8888-6. 
412 [8] M. Xie, L.D. Nghiem, W.E. Price, M. Elimelech, Toward resource recovery from wastewater: extraction of phosphorus from digested sludge using a hybrid forward osmosis-membrane distillation process, Environ. Sci. Technol. Lett. 1 (2014) 191-195. doi:10.1021/ez400189z.

[9] M.E.R. Christiaens, S. Gildemyn, S. Matassa, T. Ysebaert, J. De Vrieze, K. Rabaey, Electrochemical ammonia recovery from source-separated urine for microbial protein production, Environ. Sci. Technol. 51 (2017) 13143-13150. doi:10.1021/acs.est.7b02819.

[10] A.J. Ward, K. Arola, E. Thompson Brewster, C.M. Mehta, D.J. Batstone, Nutrient recovery from wastewater through pilot scale electrodialysis, Water Res. 135 (2018) 5765. doi:10.1016/j.watres.2018.02.021.

[11] Q. Deng, B.R. Dhar, E. Elbeshbishy, H.-S. Lee, Ammonium nitrogen removal from the permeates of anaerobic membrane bioreactors: economic regeneration of exhausted zeolite, Environ. Technol. 35 (2014) 2008-2017. doi:10.1080/09593330.2014.889759.

[12] Y.V. Nancharaiah, S. Venkata Mohan, P.N.L. Lens, Recent advances in nutrient removal and recovery in biological and bioelectrochemical systems, Bioresour. Technol. 215 (2016) 173-185. doi:10.1016/j.biortech.2016.03.129.

[13] P. Yuan, Y. Kim, Increasing phosphorus recovery from dewatering centrate in microbial electrolysis cells, Biotechnol. Biofuels. 10 (2017) 70. doi:10.1186/s13068-017-0754-8.

[14] M. Abel-Denee, T. Abbott, C. Eskicioglu, Using mass struvite precipitation to remove recalcitrant nutrients and micropollutants from anaerobic digestion dewatering centrate, Water Res. 132 (2018) 292-300. doi:10.1016/j.watres.2018.01.004.

[15] A.J. Ansari, F.I. Hai, W.E. Price, L.D. Nghiem, Phosphorus recovery from digested sludge 
centrate using seawater-driven forward osmosis, Sep. Purif. Technol. 163 (2016) 1-7. doi:10.1016/j.seppur.2016.02.031.

[16] S.G. Barbosa, L. Peixoto, B. Meulman, M.M. Alves, M.A. Pereira, A design of experiments to assess phosphorous removal and crystal properties in struvite precipitation of source separated urine using different Mg sources, Chem. Eng. J. (2016). doi:10.1016/j.cej.2016.03.148.

[17] M. Quintana, M.F. Colmenarejo, J. Barrera, E. Sánchez, G. García, L. Travieso, R. Borja, Removal of phosphorus through struvite precipitation using a by-product of magnesium oxide production (BMP): Effect of the mode of BMP preparation, Chem. Eng. J. (2008). doi:10.1016/j.cej.2007.04.002.

[18] J.L. Soler-Cabezas, J.A. Mendoza-Roca, M.C. Vincent-Vela, M.J. Luján-Facundo, L. Pastor-Alcañiz, Simultaneous concentration of nutrients from anaerobically digested sludge centrate and pre-treatment of industrial effluents by forward osmosis, Sep. Purif. Technol. 193 (2018) 289-296. doi:10.1016/j.seppur.2017.10.058.

[19] B.R. Dhar, H.-S. Lee, Evaluation of limiting factors for current density in microbial electrochemical cells (MXCs) treating domestic wastewater, Biotechnol. Reports. 4 (2014). doi:10.1016/j.btre.2014.09.005.

[20] A. Al-Mamun, M.S. Baawain, B.R. Dhar, I.S. Kim, Improved recovery of bioenergy and osmotic water in an osmotic microbial fuel cell using micro-diffuser assisted marine aerobic biofilm on cathode, Biochem. Eng. J. 128 (2017). doi:10.1016/j.bej.2017.09.020.

[21] P. Zamora, T. Georgieva, A. Ter Heijne, T.H.J.A. Sleutels, A.W. Jeremiasse, M. Saakes, C.J.N. Buisman, P. Kuntke, Ammonia recovery from urine in a scaled-up microbial 
electrolysis cell, J. Power Sources. 356 (2017) 491-499.

doi:10.1016/j.jpowsour.2017.02.089.

[22] P.T. Kelly, Z. He, Nutrients removal and recovery in bioelectrochemical systems: A review, Bioresour. Technol. 153 (2014) 351-360. doi:10.1016/j.biortech.2013.12.046.

[23] S. Haddadi, E. Elbeshbishy, H.-S. Lee, Implication of diffusion and significance of anodic pH in nitrogen-recovering microbial electrochemical cells., Bioresour. Technol. 142 (2013) 562-569. doi:10.1016/j.biortech.2013.05.075.

[24] P. Kuntke, K.M. Śmiech, H. Bruning, G. Zeeman, M. Saakes, T.H.J.A. Sleutels, H.V.M. Hamelers, C.J.N. Buisman, Ammonium recovery and energy production from urine by a microbial fuel cell, Water Res. 46 (2012) 2627-2636. doi:10.1016/j.watres.2012.02.025.

[25] M. Qin, Y. Liu, S. Luo, R. Qiao, Z. He, Integrated experimental and modeling evaluation of energy consumption for ammonia recovery in bioelectrochemical systems, Chem. Eng. J. (2017). doi:10.1016/j.cej.2017.06.182.

[26] M. Qin, C. White, S. Zou, Z. He, Passive separation of recovered ammonia from catholyte for reduced energy consumption in microbial electrolysis cells, Chem. Eng. J. (2018). doi:10.1016/j.cej.2017.11.190.

[27] R.D. Cusick, B.E. Logan, Phosphate recovery as struvite within a single chamber microbial electrolysis cell, Bioresour. Technol. 107 (2012) 110-115. doi:10.1016/j.biortech.2011.12.038.

[28] R.C. Tice, Y. Kim, Energy efficient reconcentration of diluted human urine using ion exchange membranes in bioelectrochemical systems, Water Res. 64 (2014) 61-72. doi:10.1016/j.watres.2014.06.037. 
478 [29] P. Ledezma, P. Kuntke, C.J.N. Buisman, J. Keller, S. Freguia, Source-separated urine

479

480

481

482

483

484

485

486

487

488

489

490

491

492

493

494

495

496

497

498

499

opens golden opportunities for microbial electrochemical technologies., Trends

Biotechnol. 33 (2015) 214-20. doi:10.1016/j.tibtech.2015.01.007.

[30] J. You, J. Greenman, C. Melhuish, I. Ieropoulos, Electricity generation and struvite recovery from human urine using microbial fuel cells, J. Chem. Technol. Biotechnol. 91 (2016) 647-654. doi:10.1002/jctb.4617.

[31] P. Kuntke, T.H.J.A. Sleutels, M. Saakes, C.J.N. Buisman, Hydrogen production and ammonium recovery from urine by a microbial electrolysis cell, Int. J. Hydrogen Energy. 39 (2014) 4771-4778. doi:10.1016/j.ijhydene.2013.10.089.

[32] B.S. Zakaria, S. Barua, A. Sharaf, Y. Liu, B.R. Dhar, Impact of antimicrobial silver nanoparticles on anode respiring bacteria in a microbial electrolysis cell, Chemosphere. 213 (2018) 259-267. doi:10.1016/J.CHEMOSPHERE.2018.09.060.

[33] B.R. Dhar, Y. Gao, H. Yeo, H.-S. Lee, Separation of competitive microorganisms using anaerobic membrane bioreactors as pretreatment to microbial electrochemical cells, Bioresour. Technol. 148 (2013) 208-214. doi:10.1016/j.biortech.2013.08.138.

[34] I. Joko, Phosphorus Removal from Wastewater by the Crystallization Method, Water Sci. Technol. 17 (1985) 121-132. doi:10.2166/wst.1985.0124.

[35] L.E. de-Bashan, Y. Bashan, Recent advances in removing phosphorus from wastewater and its future use as fertilizer (1997-2003), Water Res. 38 (2004) 4222-4246. doi:10.1016/j.watres.2004.07.014.

[36] J. An, H.-S. Lee, Implication of endogenous decay current and quantification of soluble microbial products (SMP) in microbial electrolysis cells, RSC Adv. 3 (2013) 14021- 
501

502

503

504

505

506

507

508

509

510

511

512

513

514

515

516

517

518

519

520

521

[37] B.E. Logan, Microbial fuel cells, Wiley-Interscience, 2008.

[38] B.R. Dhar, G. Nakhla, M.B. Ray, Techno-economic evaluation of ultrasound and thermal pretreatments for enhanced anaerobic digestion of municipal waste activated sludge, Waste Manag. 32 (2012) 542-549. doi:10.1016/j.wasman.2011.10.007.

[39] U. Mukherjee, A. Maroufmashat, J. Ranisau, M. Barbouti, A. Trainor, N. Juthani, H. ElShayeb, M. Fowler, Techno-economic, environmental, and safety assessment of hydrogen powered community microgrids; case study in Canada, Int. J. Hydrogen Energy. 42 (2017) 14333-14349. doi:10.1016/j.ijhydene.2017.03.083.

[40] C. Zhang, Y. Chen, Simultaneous nitrogen and phosphorus recovery from sludgefermentation liquid mixture and application of the fermentation liquid to enhance municipal wastewater biological nutrient removal, Environ. Sci. Technol. (2009). doi:10.1021/es9005948.

[41] H. Yuan, Y. Chen, H. Zhang, S. Jiang, Q. Zhou, G. Gu, Improved bioproduction of shortchain fatty acids (SCFAs) from excess sludge under alkaline conditions, Environ. Sci. Technol. (2006). doi:10.1021/es052252b.

[42] L. Ren, Y. Ahn, H. Hou, F. Zhang, B.E. Logan, Electrochemical study of multi-electrode microbial fuel cells under fed-batch and continuous flow conditions, J. Power Sources. 257 (2014) 454-460. doi:10.1016/j.jpowsour.2013.11.085.

[43] B.R. Dhar, H. Ryu, J.W. Santo Domingo, H.-S. Lee, Ohmic resistance affects microbial community and electrochemical kinetics in a multi-anode microbial electrochemical cell, J. Power Sources. 331 (2016) 315-321. doi:10.1016/j.jpowsour.2016.09.055. 
522 [44] S. Zou, M. Qin, Y. Moreau, Z. He, Nutrient-energy-water recovery from synthetic

523

524

525

526

527

528

529

530

531

532

533

534

535

536

537

538

539

540

541

542 sidestream centrate using a microbial electrolysis cell - forward osmosis hybrid system, J. Clean. Prod. 154 (2017) 16-25. doi:10.1016/j.jclepro.2017.03.199.

[45] Y. Luo, H. Li, Y.R. Huang, T.L. Zhao, Q.Z. Yao, S.Q. Fu, G.T. Zhou, Bacterial mineralization of struvite using $\mathrm{MgO}$ as magnesium source and its potential for nutrient recovery, Chem. Eng. J. (2018). doi:10.1016/j.cej.2018.06.106.

[46] T.L. Zhao, H. Li, Y.R. Huang, Q.Z. Yao, Y. Huang, G.T. Zhou, Microbial mineralization of struvite: Salinity effect and its implication for phosphorus removal and recovery, Chem. Eng. J. (2019). doi:10.1016/j.cej.2018.10.139.

[47] Q.-L. Chen, X.-L. An, Y.-G. Zhu, J.-Q. Su, M.R. Gillings, Z.-L. Ye, L. Cui, Application of struvite alters the antibiotic resistome in soil, rhizosphere, and phyllosphere, Environ. Sci. Technol. 51 (2017) 8149-8157. doi:10.1021/acs.est.7b01420.

[48] J.R. Cunha, C. Schott, R.D. van der Weijden, L.H. Leal, G. Zeeman, C. Buisman, Calcium addition to increase the production of phosphate granules in anaerobic treatment of black water, Water Res. 130 (2018) 333-342. doi:10.1016/j.watres.2017.12.012. 


\section{$543 \quad$ List of Figures}

544 Fig. 1. (a) Schematic diagram of MEC, and (b) various experimental schemes with MEC.

545 Fig. 2. (a) Current density profiles, (b) SCOD concentrations, (c) changes in anodic TAN

546 concentrations, and (d) changes in cathodic TAN concentrations during MEC operation with

547 centrate in Cycle-1 and Cycle-2.

548 Fig. 3. (a) Current density profiles, (b) changes in anodic TAN concentrations, (c) changes in

549 cathodic TAN concentrations, (d) SCOD concentrations, and (e) SRP concentrations during

550 MEC operation with centrate supplemented with various concentrations of exogenous readily

551 biodegradable organics (Cycle-3, 4, and 5).

552 Fig. 4. (a) Current density profiles, (b) changes in anodic TAN concentrations, (c) changes in

553 cathodic TAN concentrations, (d) SCOD concentrations, and (e) SRP concentrations during

554 MEC operation with centrate supplemented primary sludge fermentation liquor (Cycle-6 and 7).

555 Fig. 5. The changes in SRP and TAN concentrations in the anodic effluents at different doses of $556 \mathrm{Ca}^{2+}$ and $\mathrm{Mg}^{2+}$ salts.

557 Fig. 6. SEM-EDX spectrum of solid precipitates recovered from (a) $\mathrm{Ca}^{2+}{ }_{\mathrm{pH}=6.8}$ (2), and (b)

$558 \mathrm{Mg}^{2+}{ }_{\mathrm{pH}=8.6}(2)$ tests.

559

$560 \quad$ List of Tables

561 Table 1. Characteristics of centrate, primary sludge, and fermentation liquor.

562 Table 2. Summary of chemical precipitation experiments with $\mathrm{Ca}^{2+}$ and $\mathrm{Mg}^{2+}$ salts for 563 phosphorous recovery from anodic effluents. 


\section{Highlights}

- $\quad$ MEC followed by chemical precipitation was studied for N\&P recovery from centrate.

- Inadequate biodegradable COD in centrate led to ineffective $\mathrm{N}$ recovery in MEC.

- Centrate was mixed with sludge fermentation liquor to enhance $\mathrm{N}$ recovery in MEC.

- Recovered $\mathrm{H}_{2}$ gas was adequate to offset the electricity cost of MEC operation.

- $\quad$ P was efficiently recovered from MEC anodic effluent using $\mathrm{Ca}^{2+}$ or $\mathrm{Mg}^{2+}$ salts. 


\section{Graphical Abstract}

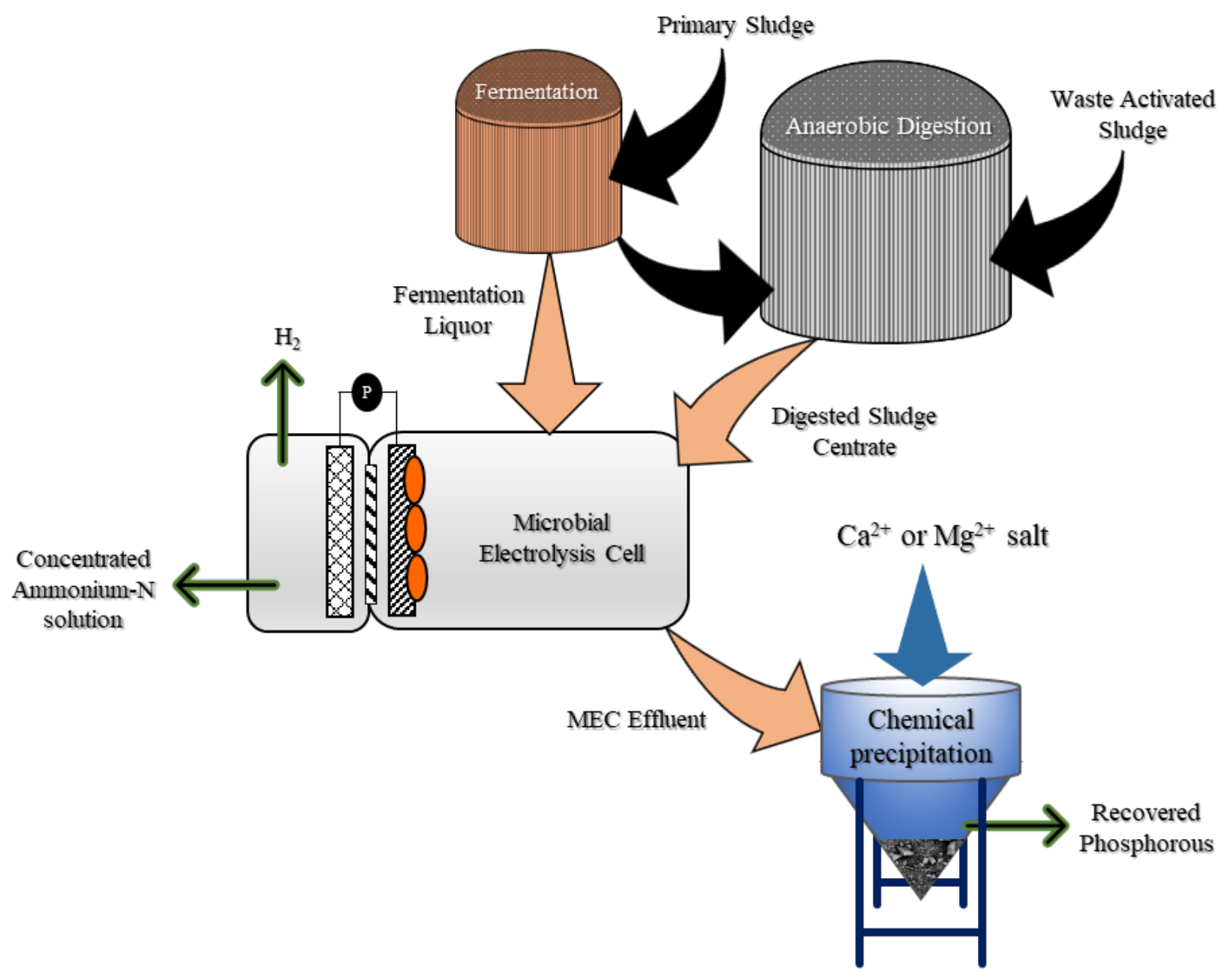




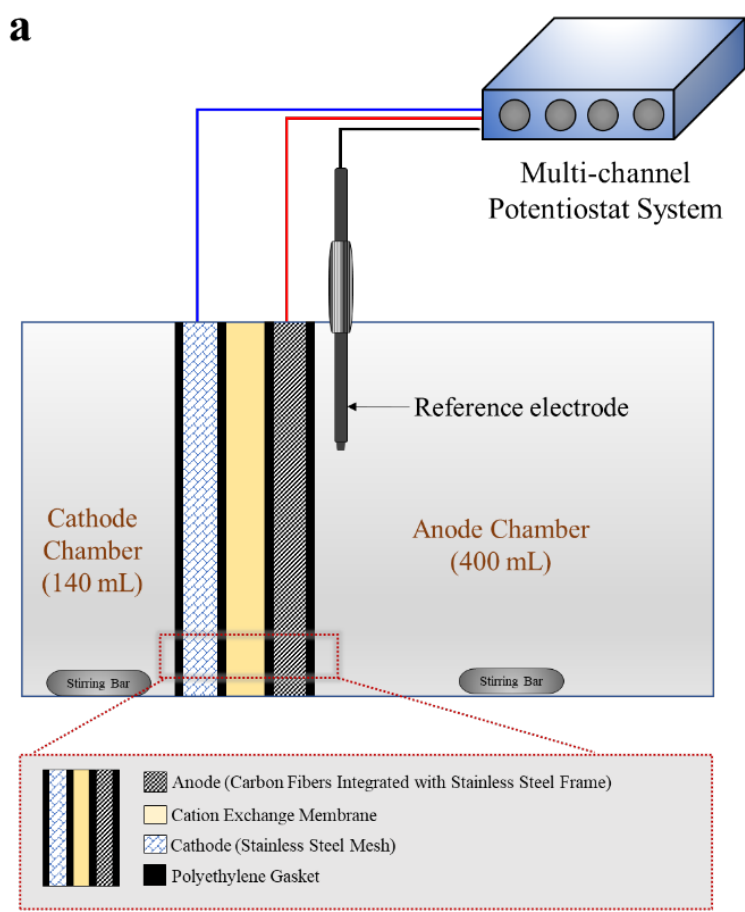

b

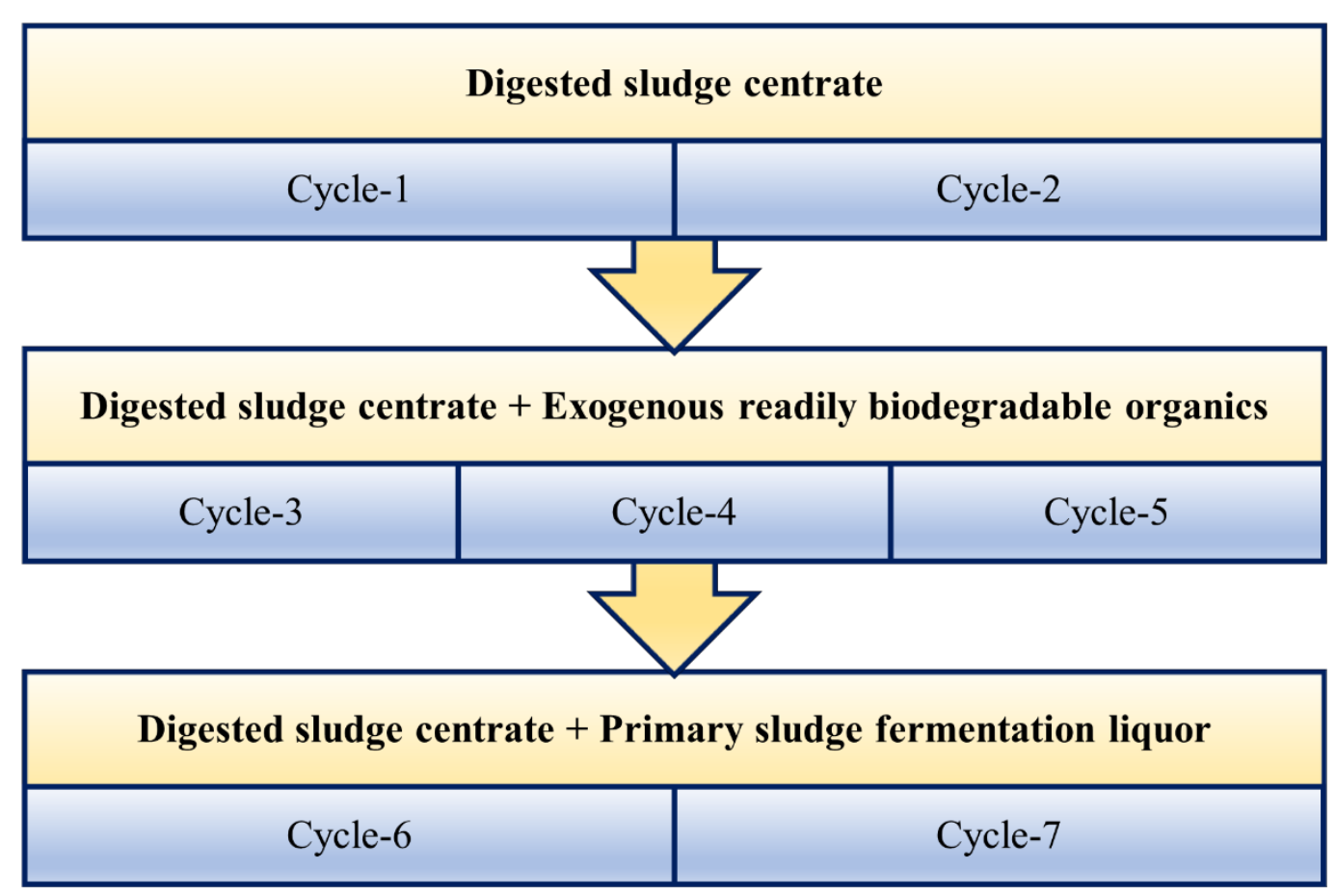

Fig. 1. (a) Schematic diagram of MEC, and (b) various experimental schemes with MEC. 

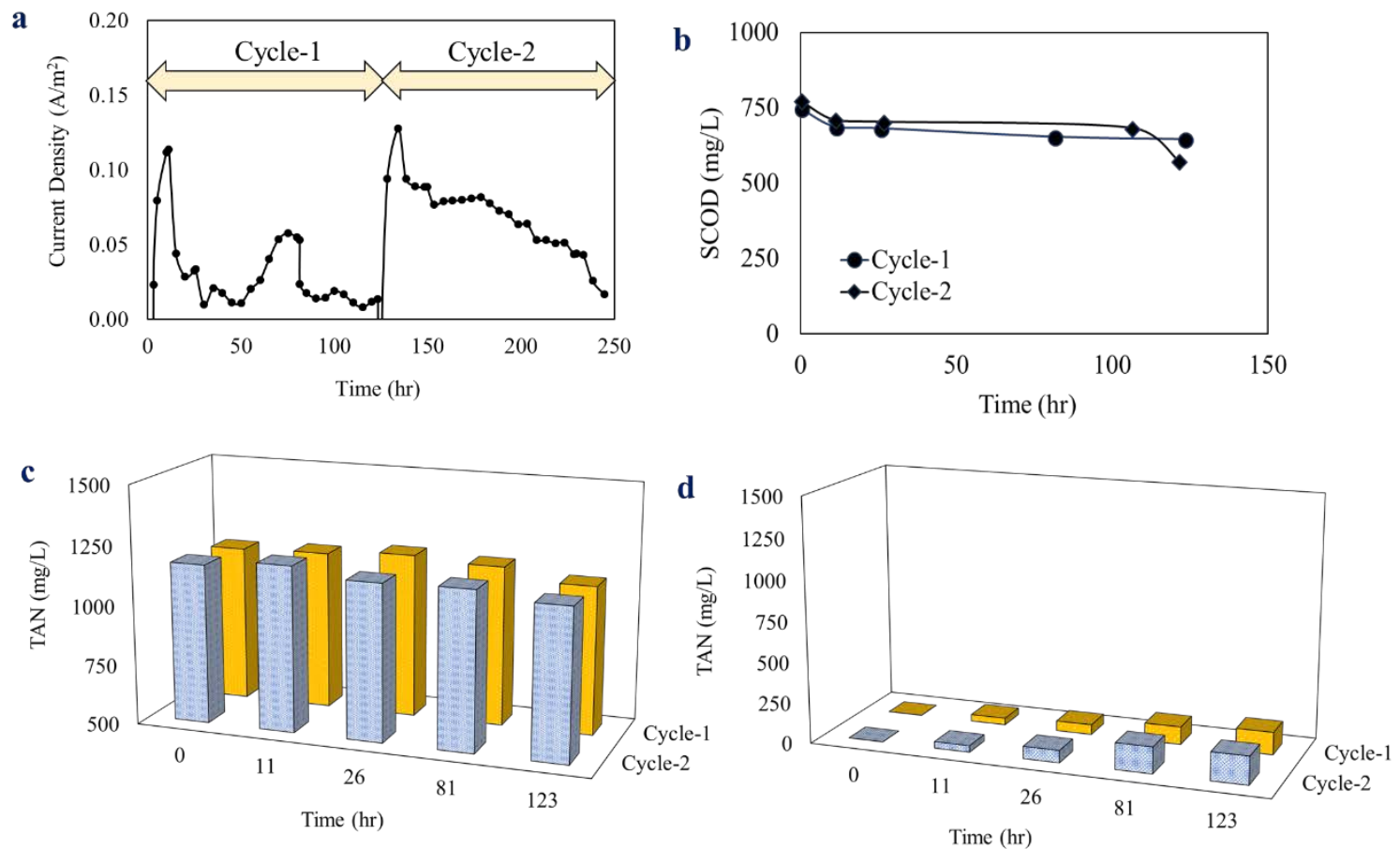

Fig. 2. (a) Current density profiles, (b) SCOD concentrations, (c) changes in anodic TAN concentrations, and (d) changes in cathodic TAN concentrations during MEC operation with centrate in Cycle-1 and Cycle-2. 
a
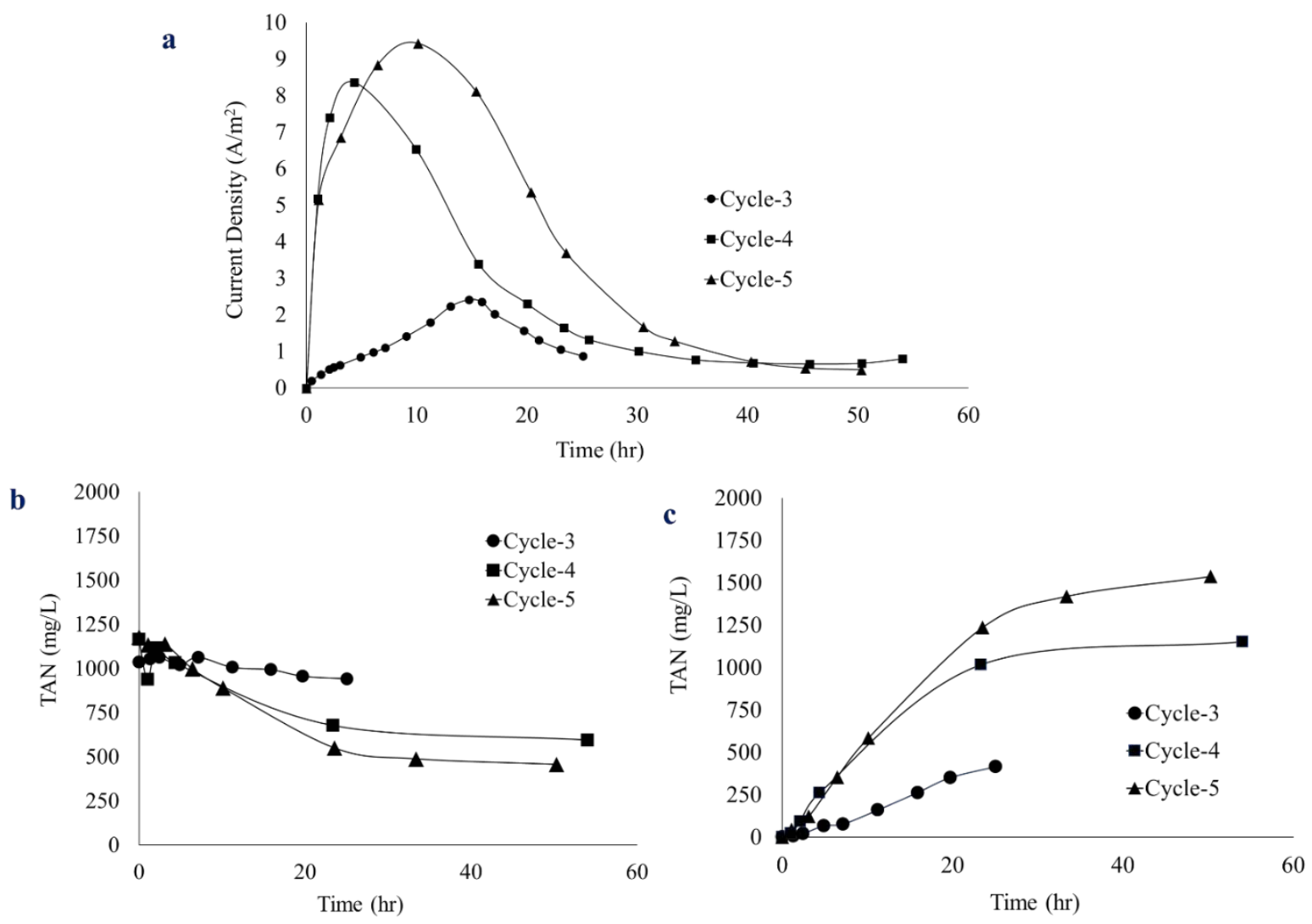

d
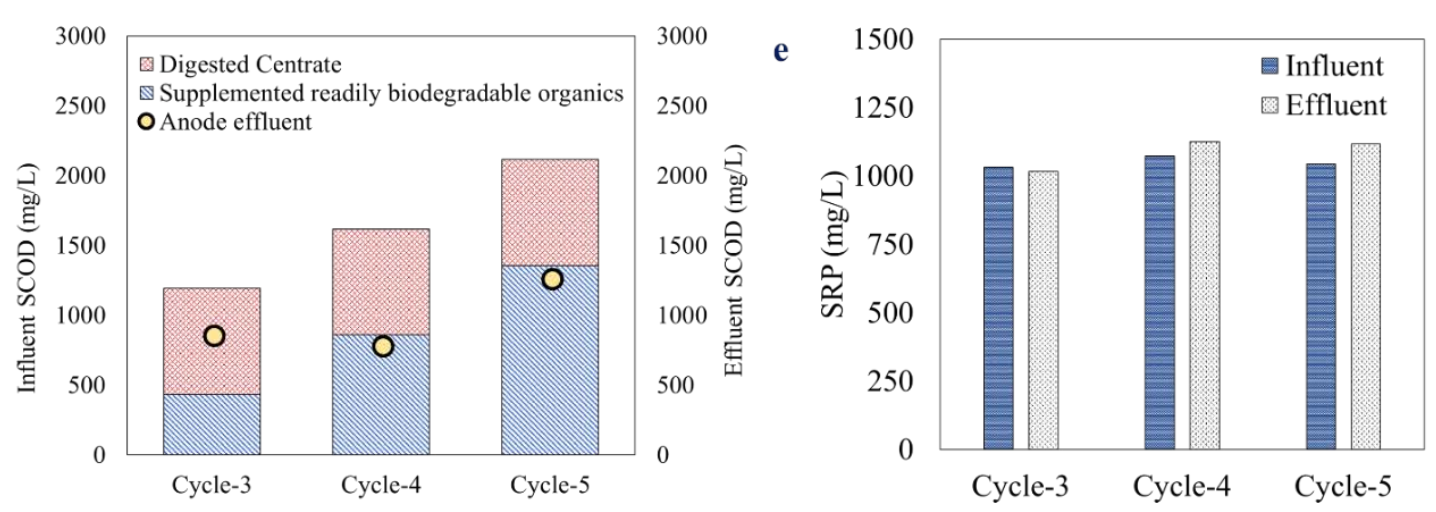

Fig. 3. (a) Current density profiles, (b) changes in anodic TAN concentrations, (c) changes in cathodic TAN concentrations, (d) SCOD concentrations, and (e) SRP concentrations during MEC operation with centrate supplemented with various concentrations of exogenous readily biodegradable organics (Cycle-3, 4, and 5). 
a

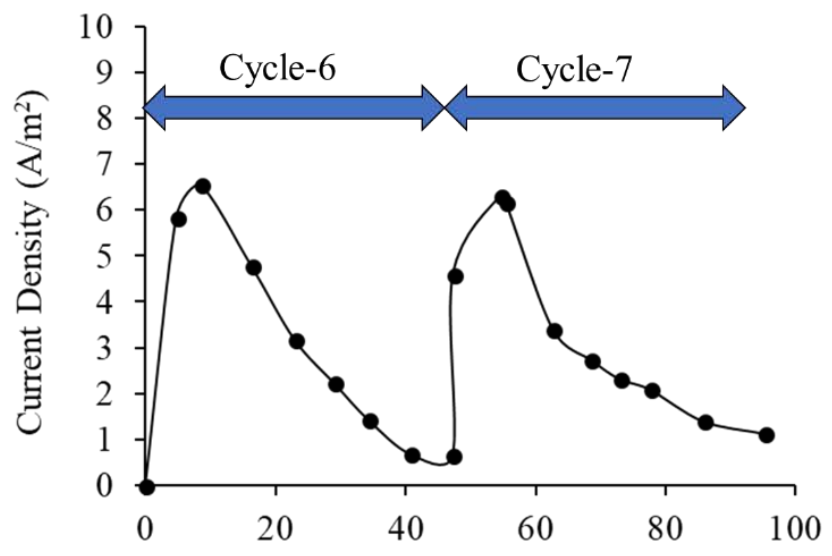

Time (hr)

b

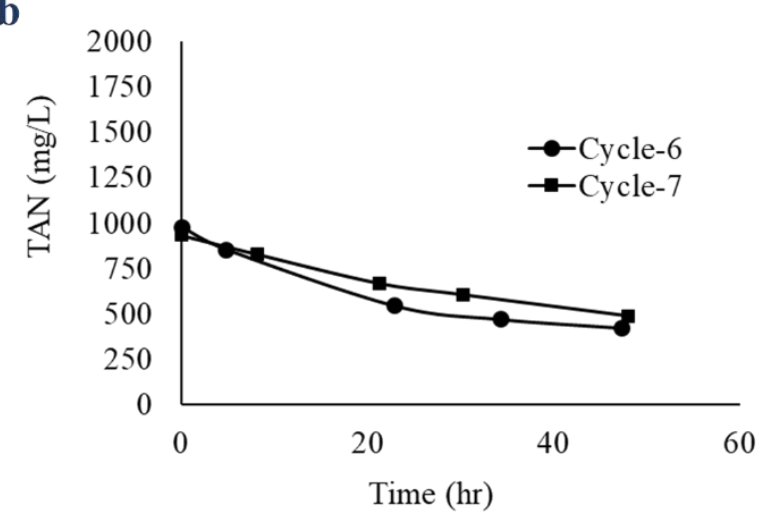

d

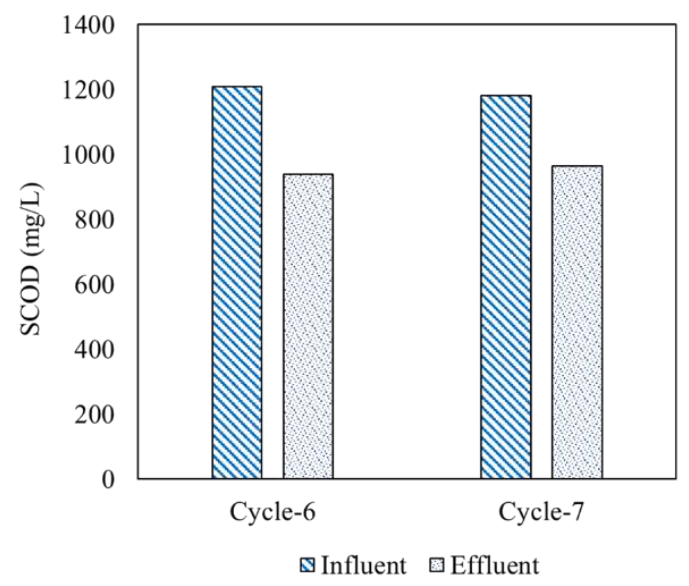

c 2000

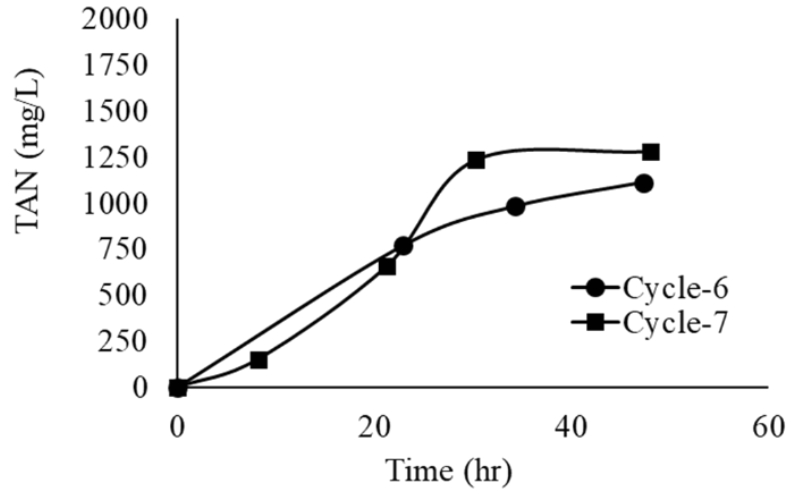

e

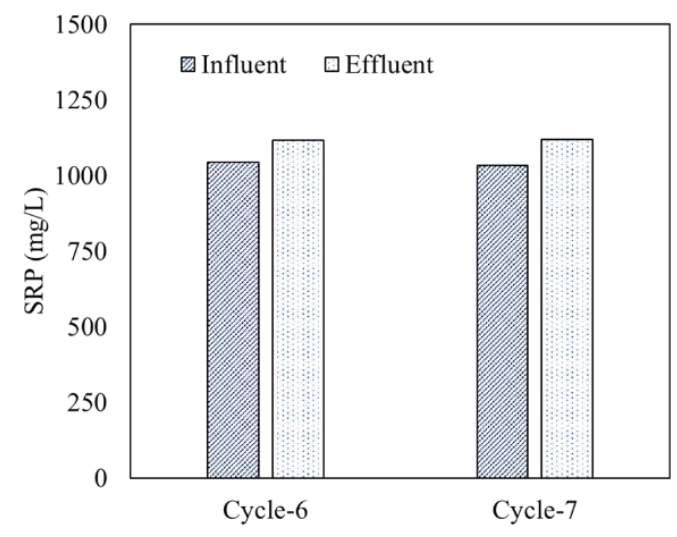

Fig. 4. (a) Current density profiles, (b) changes in anodic TAN concentrations, (c) changes in cathodic TAN concentrations, (d) SCOD concentrations, and (e) SRP concentrations during MEC operation with centrate supplemented primary sludge fermentation liquor (Cycle-6 and 7). 


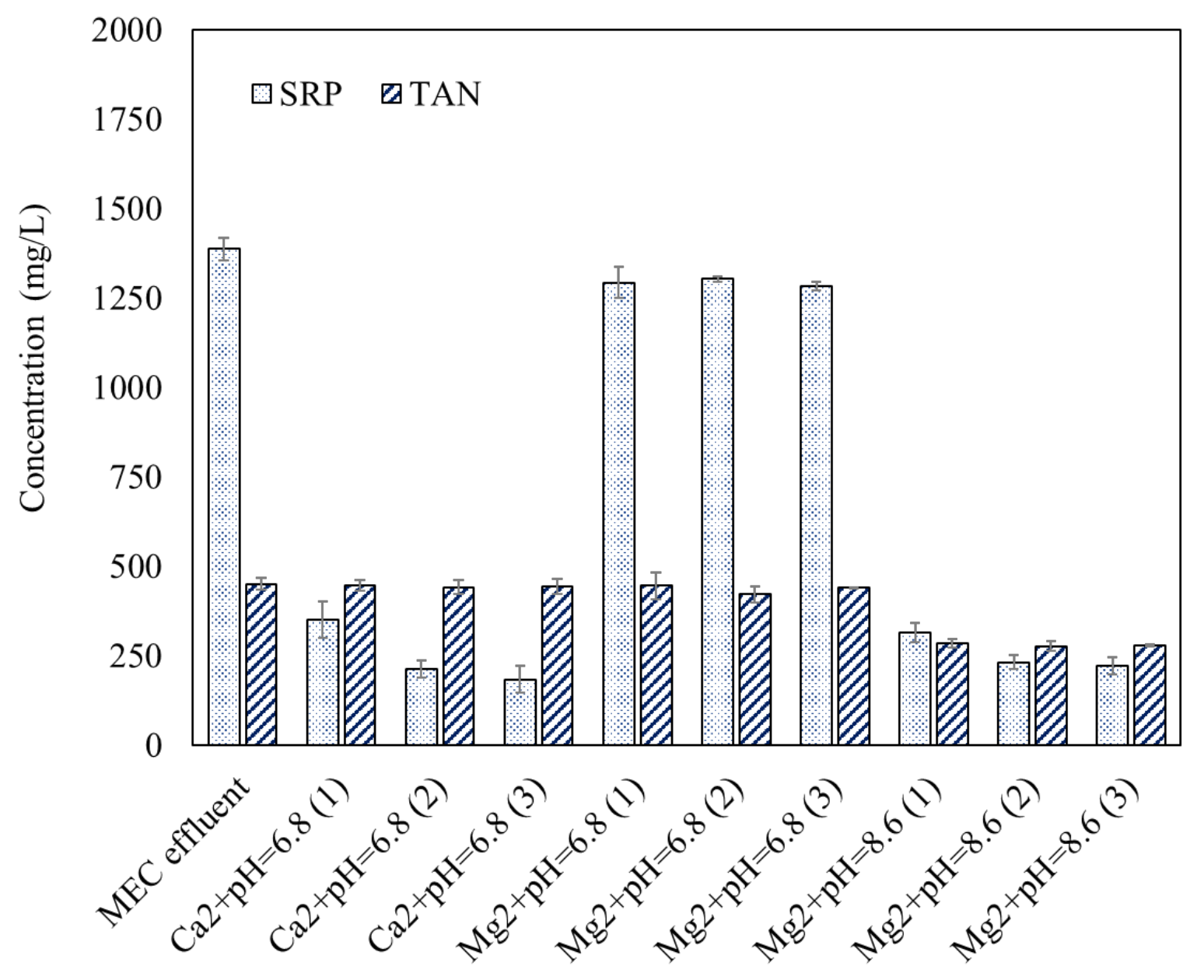

Fig. 5. The changes in SRP and TAN concentrations in the anodic effluents at different doses of $\mathrm{Ca}^{2+}$ and $\mathrm{Mg}^{2+}$ salts. 

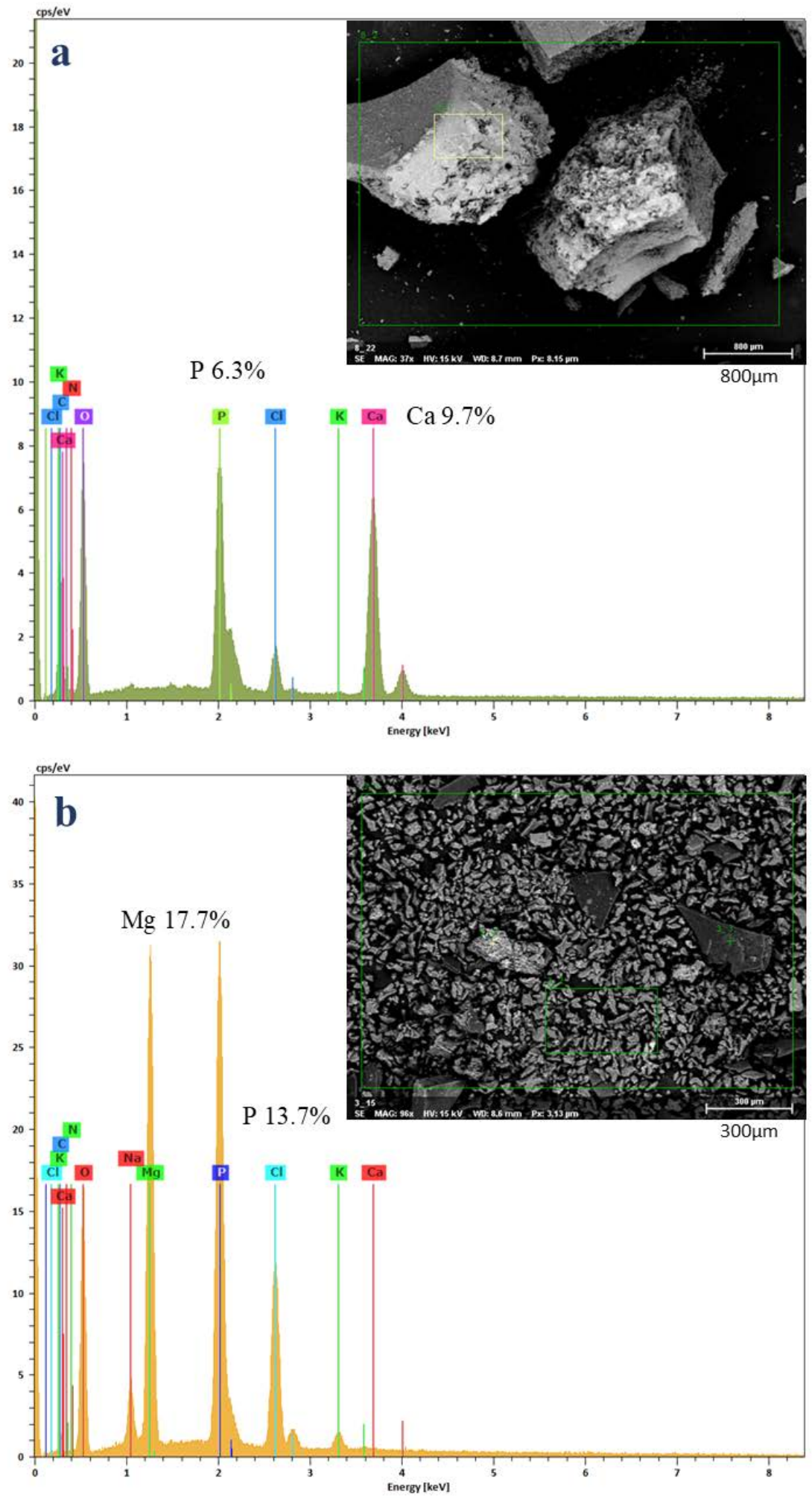

Fig. 6. SEM-EDX spectrum of solid precipitates recovered from (a) $\mathrm{Ca}^{2+}{ }_{\mathrm{pH}}=6.8$ (2), and (b) $\mathrm{Mg}^{2+}{ }_{\mathrm{pH}=8.6}(2)$ tests. 
Table 1. Characteristics of centrate, primary sludge, and fermentation liquor.

\begin{tabular}{llll}
\hline Parameter & Digested sludge centrate & Primary sludge & Fermentation liquor \\
\hline Total chemical oxygen demand, TCOD (mg/L) & $2705 \pm 130$ & $59130 \pm 580$ & $10320 \pm 208$ \\
Soluble chemical oxygen demand, SCOD (mg/L) & $740 \pm 6$ & $9770 \pm 160$ & $9292 \pm 4$ \\
Suspended solids, SS (mg/L) & $1098 \pm 333$ & $41950 \pm 1626$ & $1038 \pm 265$ \\
Total ammonia-nitrogen, TAN (mg/L) & $1177 \pm 23$ & $530 \pm 13$ & $547 \pm 5$ \\
Total volatile fatty acids, TVFA (mg COD/L) & $31 \pm 3$ & $3015 \pm 465$ & $4605 \pm 785$ \\
Soluble reactive phosphorus, SRP (mg/L) & $1387 \pm 51$ & $668 \pm 6$ & $447 \pm 3$ \\
pH & 7.9 & 6.4 & 5.5 \\
\hline
\end{tabular}


Table 2. Summary of chemical precipitation experiments with $\mathrm{Ca}^{2+}$ and $\mathrm{Mg}^{2+}$ salts for phosphorous recovery from anodic effluents.

\begin{tabular}{lllll}
\hline Set & $\mathrm{C}: \mathrm{P}^{\mathrm{c}}$ & $\mathrm{CaCl}_{2} .2 \mathrm{H}_{2} \mathrm{O}(\mathrm{g} / \mathrm{L})$ & $\mathrm{Mg}: \mathrm{P}^{\mathrm{c}}$ & $\mathrm{MgCl}_{2} .6 \mathrm{H}_{2} \mathrm{O}(\mathrm{g} / \mathrm{L})$ \\
\hline $\mathrm{Ca}^{2+}{ }_{\mathrm{pH}=6.8}(1)^{\mathrm{a}}$ & $1.5: 1$ & 3.3 & - & - \\
$\mathrm{Ca}^{2+}{ }_{\mathrm{pH}=6.8}(2)^{\mathrm{a}}$ & $3: 1$ & 6.6 & - & - \\
$\mathrm{Ca}^{2+}{ }_{\mathrm{pH}=6.8}(3)^{\mathrm{a}}$ & $4.5: 1$ & 9.9 & - & - \\
$\mathrm{Mg}^{2+}{ }_{\mathrm{pH}=6.8}(1)^{\mathrm{a}}$ & - & - & $1: 1$ & 3.1 \\
$\mathrm{Mg}^{2+}{ }_{\mathrm{pH}=6.8}(2)^{\mathrm{a}}$ & - & - & $2: 1$ & 6.2 \\
$\mathrm{Mg}^{2+}{ }_{\mathrm{pH}=6.8}(3)^{\mathrm{a}}$ & - & - & $3: 1$ & 9.3 \\
$\mathrm{Mg}^{2+}{ }_{\mathrm{pH}=8.6}(1)^{\mathrm{b}}$ & - & - & $1: 1$ & 3.1 \\
$\mathrm{Mg}^{2+}{ }_{\mathrm{pH}=8.6}(2)^{\mathrm{b}}$ & - & - & $2: 1$ & 6.2 \\
$\mathrm{Mg}^{2+}{ }_{\mathrm{pH}=8.6}(3)^{\mathrm{b}}$ & - & - & $3: 1$ & 9.3 \\
\hline
\end{tabular}

${ }^{\mathrm{a}}$ Without $\mathrm{pH}$ adjustment; ${ }^{\mathrm{b}} \mathrm{pH}$ adjusted to 8.6 ; ${ }^{\mathrm{c}}$ moler ratio 


\title{
Supplementary Information
}

\section{Microbial Electrolysis Followed by Chemical Precipitation for Effective Nutrients Recovery from Digested Sludge Centrate in WWTPs}

\author{
Sajib Barua ${ }^{1}$, Basem S. Zakaria ${ }^{1}$, Tae Chung ${ }^{1}$, Faisal I. Hai ${ }^{2}$, Tesfa Hailie ${ }^{3}$, Abdullah Al- \\ Mamun $^{4}$, Bipro Ranjan Dhar ${ }^{1^{*}}$ \\ ${ }^{1}$ Civil and Environmental Engineering, University of Alberta, 9211-116 Street NW, Edmonton, \\ AB, Canada T6G 1H9 \\ ${ }^{2}$ Strategic Water Infrastructure Laboratory, School of Civil, Mining and Environmental \\ Engineering, University of Wollongong, Wollongong, NSW 2522, Australia \\ ${ }^{3}$ InnoTech Alberta, 1 Oil Patch Drive, Devon, AB, Canada T9G 1A8 \\ ${ }^{4}$ Civil and Architectural Engineering, Sultan Qaboos University, Al-Khoud 123, Muscat, \\ Sultanate of Oman
}

*Corresponding author: Bipro Ranjan Dhar

Phone: +1-780-248-1923

E-mail: bipro@ualberta.ca 


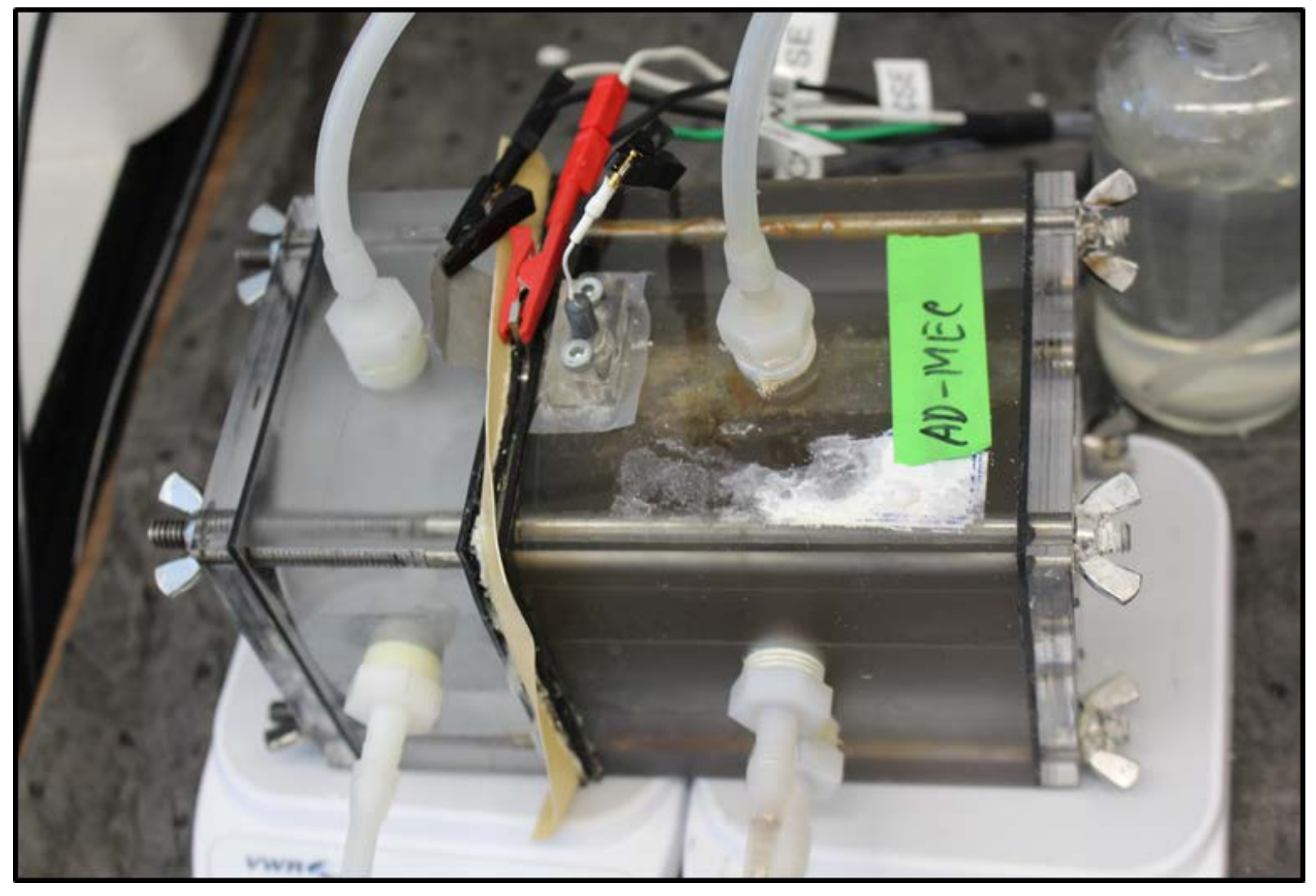

Fig. S1. Photograph of microbial electrolysis cell (MEC) used in this study. 

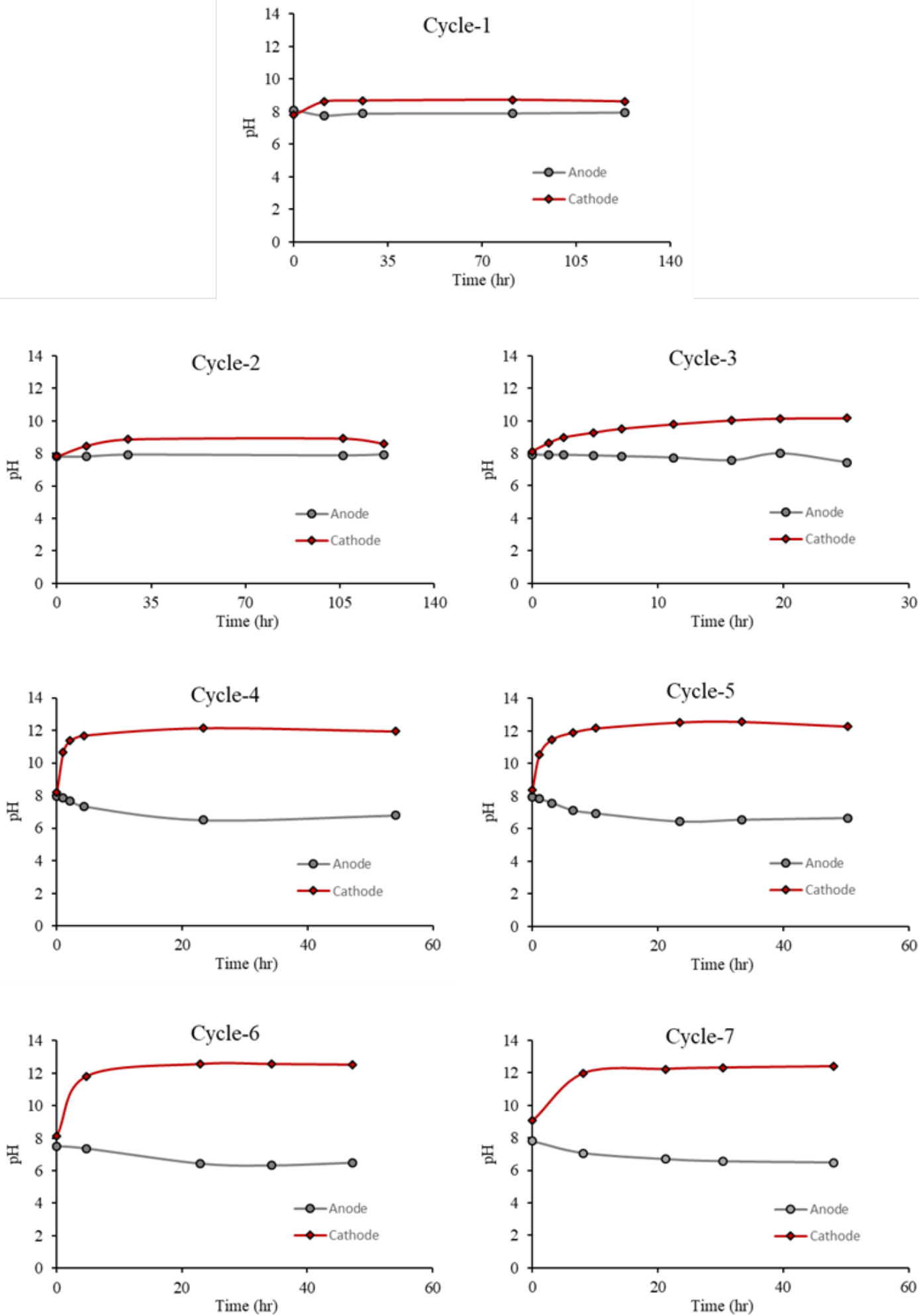

Fig. S2: pH profiles of anode and cathode chamber during different operating cycles. 
Table S1. Summary of pH and conductivity at the end of chemical precipitation experiments with $\mathrm{Ca}^{2+}$ and $\mathrm{Mg}^{2+}$ salts for phosphorous recovery from MEC effluents.

\begin{tabular}{lll}
\hline Set & $\mathrm{pH}$ & Conductivity \\
\hline $\mathrm{Ca}^{2+}{ }_{\mathrm{pH}=6.8}(1)$ & $6.1 \pm 0.1$ & $6.89 \pm 0.43$ \\
$\mathrm{Ca}^{2+}{ }_{\mathrm{pH}=6.8}(2)$ & $5.8 \pm 0.1$ & $11.17 \pm 0.03$ \\
$\mathrm{Ca}^{2+}{ }_{\mathrm{pH}=6.8}(3)$ & $5.7 \pm 0.1$ & $15.35 \pm 0.04$ \\
$\mathrm{Mg}^{2+}{ }_{\mathrm{pH}=6.8}(1)$ & $6.8 \pm 0$ & $6.74 \pm 0.04$ \\
$\mathrm{Mg}^{2+}{ }_{\mathrm{pH}=6.8}(2)$ & $6.7 \pm 0$ & $9.23 \pm 0.01$ \\
$\mathrm{Mg}^{2+}{ }_{\mathrm{pH}=6.8}(3)$ & $6.6 \pm 0$ & $11.82 \pm 0.15$ \\
$\mathrm{Mg}^{2+}{ }_{\mathrm{pH}=8.6}(1)$ & $7.3 \pm 0.1$ & $6.15 \pm 0.02$ \\
$\mathrm{Mg}^{2+}{ }_{\mathrm{pH}=8.6}(2)$ & $7.1 \pm 0$ & $8.64 \pm 0.01$ \\
$\mathrm{Mg}^{2+}{ }_{\mathrm{pH}=8.6}(3)$ & $7 \pm 0$ & $11.3 \pm 0.01$ \\
\hline
\end{tabular}

